\title{
Diet of Physalaemus cf. cicada (Leptodactylidae) and Bufo granulosus (Bufonidae) in a semideciduous forest
}

\author{
Santana, AS.* and Juncá, FA.* \\ Departamento de Ciências Biológicas, Universidade Estadual de Feira de Santana, \\ Av. Universitária s/n, Campus Universitário, CEP 44031-460, Feira de Santana, BA, Brazil \\ *e-mail: assantana_bio@yahoo.com.br, florajunca@yahoo.com.br \\ Received December 27, 2004 - Accepted March 9, 2005 - Distributed February 28, 2007
}

(With 4 figures)

\begin{abstract}
We determined the diet of the two most abundant anuran species which occur in the litter of a semideciduous forest (Lençóis, Bahia, Brazil), Physalaemus cf. cicada and Bufo granulosus in the dry and rainy seasons. Pitfall traps were used to collect anuran and invertebrate fauna, which showed the availability of prey in the environment. Physalaemus cf. cicada was present in both seasons and Bufo granulosus only in the rainy season. Both species fed mainly on Isoptera and Formicidae. However, there is a difference between the rainy and dry seasons concerning the diet of $P$. cf. cicada. During the rainy season $P$. cf. cicada consumed less Isoptera and more Formicidae than in the dry season. In the volumetric sense, Orthoptera was the most important alimentary category for $P$. cf. cicada and B. granulosus. The Jacobs' electivity index indicated that Physalaemus cf. cicada and Bufo granulosus were specialists in Isoptera.
\end{abstract}

Keywords: Physalaemus cf. cicada, Bufo granulosus, diet, seasonality.

\section{Dieta de Physalaemus cf. cicada (Leptodactylidae) e Bufo granulosus (Bufonidae) em uma floresta semidecídua}

\begin{abstract}
Resumo
Foi determinada a dieta das duas espécies mais abundantes de anuros que ocorrem na serrapilheira de uma floresta semidecídua (Lençóis, Bahia, Brasil), Physalaemus cf. cicada e Bufo granulosus, nas estações seca e chuvosa. Armadilhas de queda foram usadas para a coleta de anuros e fauna de invertebrados que indicaram a disponibilidade de presas no ambiente. Physalaemus cf. cicada estava presente em ambas as estações e Bufo granulosus, só na estação chuvosa. Ambas as espécies alimentaram-se principalmente de Isoptera e Formicidae. Porém, houve uma diferença entre estações chuvosa e seca relativo à dieta de $P$. cf. cicada. Durante a estação chuvosa, $P$. cf. cicada consumiu menos Isoptera e mais Formicidae que na estação seca. Volumetricamente, Orthoptera foi a categoria alimentar mais importante para P. cf. cicada e B. granulosus. O índice de eletividade de Jacobs indicou que Physalaemus cf. cicada e Bufo granulosus são especialistas em Isoptera.
\end{abstract}

Palavras-chave: Physalaemus cf. cicada, Bufo granulosus, dieta, sazonalidade.

\section{Introduction}

Various factors may influence the diet and alimentary habits of anurans, including seasonal changes in food availability, competitor presence, size, specializations and ecological tolerance of the different species (Duellman and Trueb, 1994). According to the diet, Toft (1980) divided the anuran species into three large groups: i) specialists represented by many species of the Bufonidae, Microhylidae and Dendrobatidae families and characterized by the preference of some arthropods, often Formicidae; ii) non-ant specialists from the Leptodactylidae and Hylidae families, which tend to reject ants and feed on other kinds of prey; and iii) gen- eralists from different families, which feed on several prey, but within proportions similar to those found in the envrironment.

Associated to the diet type, Toft (1981) observed that the species could show particular morphologic characteristics and two kinds of foraging behaviour. The specialists generally present an active foraging behaviour, in which the animal searches for its food. The number of consumed prey is relatively large and they are often small, chitinous, tend to form groups and have chemical defences, such as ants and termites. On the other hand, non-ant specialist species and generalists show a "sit and

This article was prepared before the taxonomic porposals of Frost et al. (2006) and Grant et al. (2006). Using these new taxonomic arrangement Buffo granulosus is included in the genus Chaunus and Physalaemus is reallocated to Leiuperidae. 
wait" behaviour and feed on a smaller amount of prey, although of a larger size. These last two types of predators have a larger mouth when compared to the active predators (Strüssmann et al., 1984; Toft, 1980a).

In this work, we studied the diet of the two most abundant species of anurans that occur in the litter of a semideciduos forest, located at Lençóis, Bahia. They are: Bufo granulosus Spix and Physalaemus cf. cicada Bokermann. The Physalaemus genus has several various taxonomic problems and some groups of species of this genus are difficult to identify at a specific level. Although we compared the collected specimens with the Physalaemus collection from the Museum of Zoology (University of São Paulo - MZUSP), including the type series of Physalaemus cf. cicada, we prefer to use Physalaemus cf. cicada. Up to now a few studies have been done on the diet of species of the genus Physalaemus and the genus Bufo (for a revision see Parmelle, 1999) and nothing is known about the species focused on in this work.

\section{Material and Methods}

This work was performed in a semideciduous forest located between the rivers São José and Santo Antônio at Lençóis, Chapada Diamantina, state of Bahia, Brazil (12 $33^{\prime} 47^{\prime}$ S and $41^{\circ} 23^{\prime} 18^{\prime \prime} \mathrm{W}$ at $455 \mathrm{~m}$ high). The climate in this region is humid to subhumid with an annual precipitation of 800-1200 mm, and from November to January most precipitation occurs (CEPLAB, 1978). The samples were taken on two occasions: on July, from the $13^{\text {th }}$ to $22^{\text {nd }} 1998$ (dry season) and on February $20^{\text {th }}$ until March $3^{\text {rd }} 1999$ (rainy season). In order to capture the animals, we used 96 pitfall traps made from buckets (capacity of $20 \mathrm{~L}$ ), buried in the soil up to the border. Six sample points were installed following a road that crosses the forest, linking the city of Lençóis to Marimbus, a village $15 \mathrm{~km}$ far from Lençóis. In each sample point 16 pitfalls were placed in the shape of an "L". Between the pitfalls, plastic supports were installed in order to direct the animals to the traps. These pitfalls were checked daily and all anurans were collected. To obtain data on the availability of food in the environment, the arthropods imprisoned in three of the 16 buckets (at the ends and at the corner of the "L") were also collected.

The anurans were fixed in the field in a $10 \%$ formaldehyde solution and kept in a 70\% alcohol solution. In the laboratory, the snout-vent length (SVL) and mouth length were obtained using a calliper. The collected arthropods were identified up to the level of order or family. The contents of the gastrointestinal tract of the anurans were analysed quantitatively (number of individuals) and qualitatively (i.e.. the taxa were identified). The food items were also measured (length and width) using a millimetre scale. From these body dimensions the volume was calculated, thus estimating the size of the consumed prey by the formula used by Caldwell and Vitt (1999): $\mathrm{V}=4 / 3 \pi\left(\right.$ length/2) $(\text { width } / 2)^{2}$
The average of volume of ingested items (Vi) was calculated by the amount (sum) of the volume of all items $(\Sigma \mathrm{V})$ divided by the number of individuals $(n)$ : $\left(\mathrm{Vi}=\frac{\sum \mathrm{V}}{n}\right)$. The average of volume of each category (Vc) was calculated by the amount (sum) of the volumes of all items of category $\mathrm{x}\left(\Sigma \mathrm{Vc} \mathrm{c}_{\mathrm{x}}\right)$ divided by the number of items in the category $\mathrm{x}\left(n_{\mathrm{x}}\right):\left(\mathrm{Vc}=\frac{\sum \mathrm{Vc}_{\mathrm{x}}}{n_{\mathrm{x}}}\right)$. The relation between $\mathrm{Vi} / \mathrm{Vc}$ showed the amount of items each food category should consume to reach the average of volume of items per individual.

For each category of prey, established from the taxonomic identity, the frequency of occurrence was calculated. In other words, the amount of gastrointestinal tracts that presented certain categories of food items. Moreover, the numeric frequency, that provides the amount of each of these categories in the gastrointestinal tracts, was also calculated.

To establish the preference for prey category, the electivity index was calculated, from the index proposed by Jacob (1974): $\mathrm{D}=\frac{\mathrm{dk}-\mathrm{fk}}{\mathrm{dk}+\mathrm{fk}-2 \mathrm{dkfk}}$. Where $\mathrm{dk}$ is the proportion of prey from category $\mathrm{k}$ in the gastrointestinal tract, and $\mathrm{fk}$ is the proportion of prey of category $\mathrm{k}$ in the environment. $\mathrm{D}$ varies from +1 , to complete selection or preference of prey of category $\mathrm{k}$ (indicating, therefore, a specialist species); zero, when prey $\mathrm{k}$ is found at the same proportion from that found in the environment; to -1 , when prey $\mathrm{k}$ is absent in the diet and present in the environment (indicating that the species rejects this kind of prey).

The sex of the individuals was determined by observing the gonads. All individuals whose sex could not be identified were considered young. The material used in this work is deposited in the Museu de Zoologia da Universidade Estadual de Feira de Santana (MZUEFS)

\section{Results}

During the dry season, individuals of Physalaemus cf. cicada $(\mathrm{N}=63)$ and Dermatonotus muelleri $(\mathrm{N}=2)$ were observed. In the rainy season, individuals of P. cf. cicada $(\mathrm{N}=107)$, D. muelleri $(\mathrm{N}=10), B$. granulosus $(\mathrm{N}=165)$ Physalaemus cf. centralis $(\mathrm{N}=7)$, Bufo jimi $(\mathrm{N}=7)$, Leptodactylus troglodytes $(\mathrm{N}=4)$ and Leptodactylus aff. mystaceus $(\mathrm{N}=1)$ were observed.

\subsection{Food availability}

We found 2,040 arthropods in the dry season and 2,514 in the rainy season distributed into 20 and 19 taxa respectively. Formicidae, Orthoptera, Araneae and Coleoptera were the most abundant taxa in both seasons. Isoptera, whose presence was very small in the rainy season, was abundant in the dry season, while Acari was more abundant in the rainy season (Figure 1). The other identified taxa (Thysanura, Scorpiones, Blattodea, Chilopoda, Dermaptera, Mantodea, Homoptera, Pseudoescorpiones, Diplopoda in both seasons, larvae of Lepdoptera in the dry season, and Neuroptera in the 


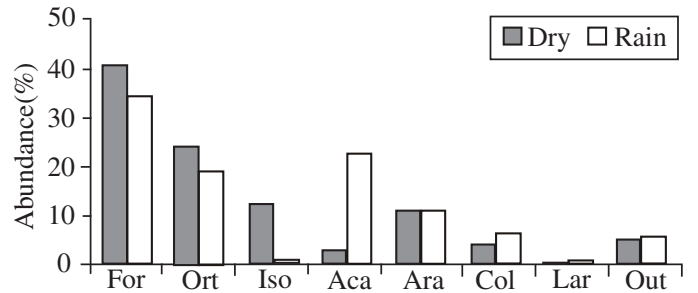

Figure 1. Availability of different categories of arthropods $(\%)$ in the environment in the dry and rainy seasons. For $=$ Formicidae, Ort $=$ Orthoptera, Iso $=$ Isoptera, Aca $=$ Acari, Ara $=$ Araneae, $\mathrm{Col}=$ Coleoptera, Lar $=$ Larvae, Out $=$ Others

rainy season) were grouped in "Others" since they were present in very small numbers.

\subsection{Physalaemus cf. cicada in both seasons}

We analysed 100 specimens of Physalaemus cf. cicada, 23 males and 27 females in the dry season and 23 males, 3 young and 24 females in the rainy season. We found 679 food items in the dry season with an average of 14 prey/specimen $(\bar{X}=13.6$; $\mathrm{SD}=19.1$; range $1-100)$, and 526 food items in the rainy season with 11 prey/specimen $(\bar{X}=10.5 ; S D=9.1$; range $1-47)$. Only five individuals $(10 \%)$ in the dry season did not present items in the gastrointestinal tract.

In both seasons Isoptera, Formicidae and Orthoptera were consumed, while Coleoptera, only in the rainy season. In the dry season the taxa Chilopoda, Araneae, Thysanura, Acari, and Hemiptera were found in very small amounts and were considered as "Others". In the rainy season, besides the taxa mentioned for the dry season, Dermaptera, Gastropoda, Blattodea and larvae of Diptera were also included in the category "Others". Isoptera was present in more than $80 \%$ of the sampled individuals in the two seasons, while Formicidae presented a greater frequency of occurrence in the rainy season than in dry season (Figure 2a). The category Isoptera was also the most important quantitatively, while Formicidae, although it was the second most consumed, presented a low numeric frequency (Figure 2a, b).

In both seasons, $P$. cf. cicada basically used prey with a volume from 0.1 to $5.0 \mathrm{~mm}^{3}$, and we observed an increase in consumption of large prey in the rainy season (Figure 2d). Volumetrically, Orthoptera was the most important category in the diet of $P$. cf. cicada (Figure 2c). On the other hand, although Formicidae was an important category in occurrence, the amount of ants that one individual would need to consume to reach the average of total volume of prey per individual was much higher when compared to Isoptera (Figure 3a). The electivity indexes (D) found for Isoptera were high in the two seasons, while the other categories showed negative indexes (Table 1). For Formicidae, during the rainy season it was close to zero, and in the dry season close to -1 .

Physalaemus cf. cicada presented SVL varying from $18.9 \mathrm{~mm}$ to $29.2 \mathrm{~mm}(\overline{\mathrm{X}}=25 ; \mathrm{SD}=2.8, \mathrm{~N}=50)$ in the
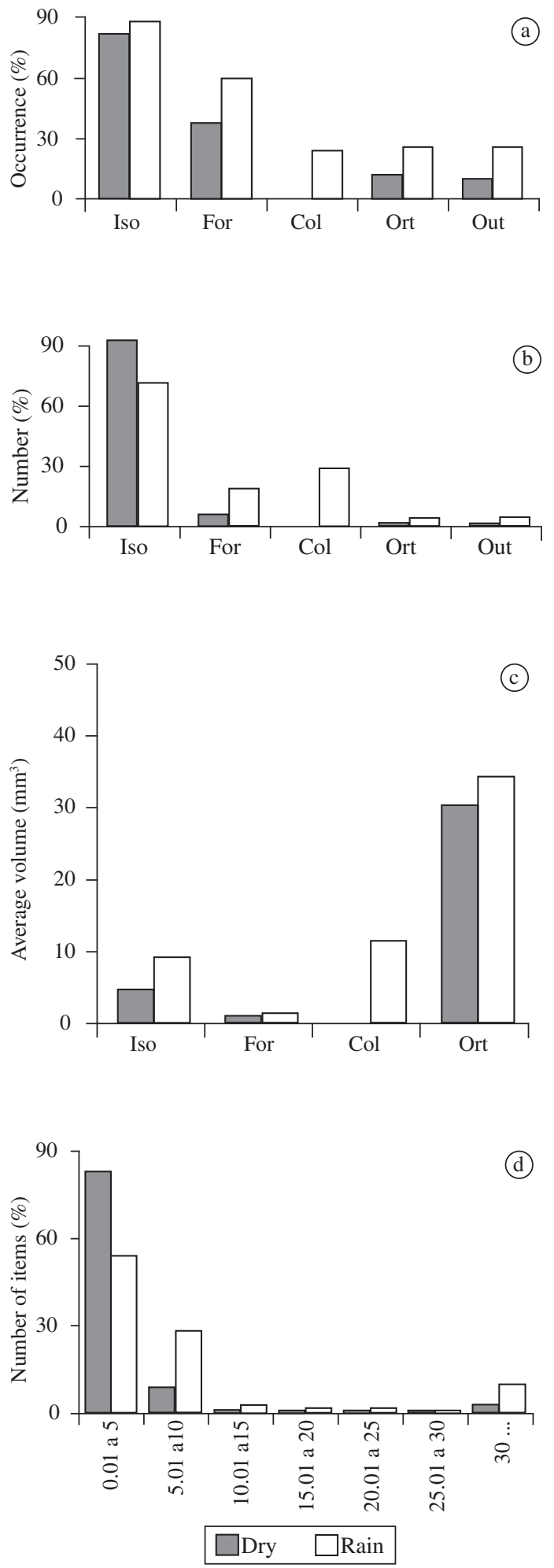

Figure 2. Frequency of occurrence a), numeric frequency b), average volume per category c) and number of items in different volumetric categories d) in Physalaemus cf. cicada in the dry and rainy seasons. Iso $=$ Isoptera, For $=$ Formicidae, $\mathrm{Col}=$ Coleoptera, Ort $=$ Orthoptera, Out $=$ Others . 

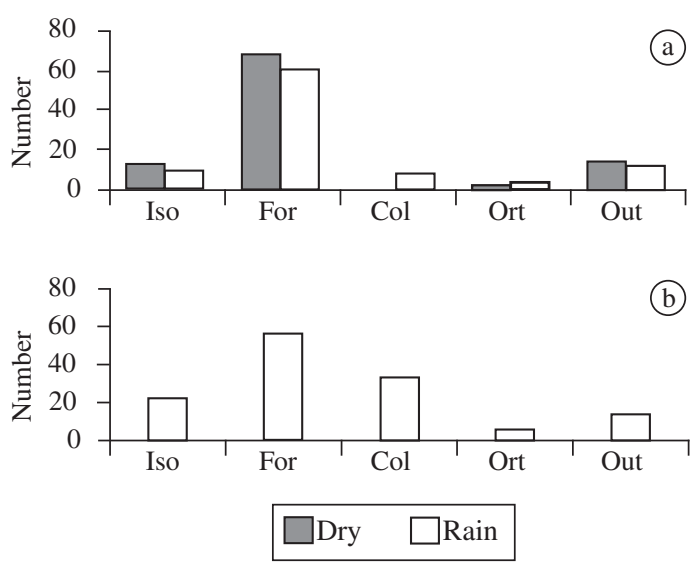

Figure 3. Number of items of each category necessary to reach the average of total volume of prey per individual to Physalaemus cf. cicada a); and Bufo granulosus b). Iso $=$ Isoptera, For $=$ Formicidae, $\mathrm{Col}=$ Coleoptera, Ort $=$ Orthoptera, Out $=$ Others

Table 1. Values for the electivity index to Physalaemus cf. cicada in the dry and rainy seasons and to Bufo granulosos in the rainy season.

\begin{tabular}{lccc}
\hline & \multicolumn{2}{c}{$\begin{array}{c}\text { Physalaemus cf. } \\
\text { cicada }\end{array}$} & Bufo granulosus \\
& Dry & Rain & Rain \\
\hline Isoptera & 0.98 & 1.00 & 0.99 \\
Formicidae & -0.86 & -0.40 & -0.15 \\
Orthoptera & -0.93 & -0.71 & -0.99 \\
Coleoptera & - & -0.39 & -0.52 \\
Others & -0.92 & -0.88 & -0.98 \\
\hline
\end{tabular}

dry season, and from $15.7 \mathrm{~mm}$ to $30.8 \mathrm{~mm}(\overline{\mathrm{X}}=24.5$; $\mathrm{SD}=3.1 ; \mathrm{N}=50)$ in the rainy season. The mouth length ranged from 3.8 to $6.9 \mathrm{~mm}(\overline{\mathrm{X}}=5.6 ; \mathrm{SD}=0.7 ; \mathrm{N}=50)$ in the dry season, and from 4.1 to $6.6(\bar{X}=5.4 ; \mathrm{SD}=0.7$, $\mathrm{N}=50$ ) in the rainy season. There were significant positive correlations between the SVL and the mouth length in both seasons (Pearson correlation coefficients: $r=0.70$, $\mathrm{N}=50, \mathrm{p}<0.001$ for the dry season, and $\mathrm{r}=0.77 \mathrm{~N}=50$, $\mathrm{p}<0.001$ for the rainy season). The maximum volume of the consumed prey did not present a significant positive correlation, neither with the snout-vent length (Pearson correlation coefficients: $\mathrm{r}=0.20, \mathrm{~N}=50, \mathrm{p}>0.05$ ) or mouth length (Pearson correlation coefficients: $r=0.20$, $\mathrm{N}=50, \mathrm{p}>0.05)$ the dry season. However, there were a significant positive correlation between the maximum volume of the consumed prey with both snout-vent length (Pearson correlation coefficients: $\mathrm{r}=0.39, \mathrm{~N}=50$, $\mathrm{p}<0.02$ ) and mouth length (Pearson correlation coefficients: $r=0.41, \mathrm{~N}=50, \mathrm{p}<0.05)$ in the rainy season.

In the rainy season, three individuals $(6 \%)$ presented the rest of the vegetal material and six other individuals
$(12 \%)$ contained sand grains. In the dry season, only one stomach had sand. In a few individuals, nematods were also found associated to the intestines. In the dry season 13 nematodes $(\overline{\mathrm{X}}=1.2 ; \mathrm{DP}=0.4, \mathrm{~N}=11)$ were found and in the rainy season, 7 nematodes $(\overline{\mathrm{X}}=1.8 ; \mathrm{DP}=1.5$, $\mathrm{N}=4$ ).

\subsection{Bufo granulosus}

A total of 64 specimens ( 31 males and 33 females) were analysed. Their gastrointestinal tracts contained food items belonging to the following categories: Isoptera, Formicidae, Coleoptera, and Others (Araneae, Dermaptera, Hemiptera, Orthoptera, Collembola and Pseudoescorpione). In total, 1,718 items were checked, and, on average, 27 items were found per specimen $(\bar{X}=26.8 ; \mathrm{SD}=14.1$, range $1-111)$. Only one individual of Bufo granulosus presented the gastrointestinal tract as empty. The frequency of occurrence of Isoptera in the diet of Bufo granulosus (84\%) was similar to that found for P. cf. cicada (88\%). Formicidae presented the largest frequency of occurrence (Figure 4a), although the numeric frequency of Isoptera was much larger (Figure $4 \mathrm{~b}$ ). Coleoptera was the third item most consumed by $B$. granulosus.

Although the volume of prey varied from 0.03 to $117.8 \mathrm{~mm}^{3}(\overline{\mathrm{X}}=11.5 ; \mathrm{SD}=15, \mathrm{~N}=1718)$, B. granulosus similarly to P. cf. cicada, fed basically on prey from 0.1 to $5.0 \mathrm{~mm}^{3}$ (Figure 4d). Orthoptera was the most important item volumetrically (Figure 4c). However, this category was not consumed much. The amount of ants that each individual would need to consume to reach the average volume/individual was approximately the triple amount of Isoptera (Figure $3 \mathrm{~b}$ ), highlighting thus the relevance of this last category in the diet of B. granulosus. The electivity index obtained for Isoptera was high, while for the category Formicidae it was close to zero (Table 1).

The SVL of Bufo granulosus varied from 24.9 to $43.2 \mathrm{~mm}(\overline{\mathrm{X}}=31.9 ; \mathrm{SD}=4.2 ; \mathrm{N}=64)$ and the mouth length varied from 5.5 to $9.2 \mathrm{~mm}(\overline{\mathrm{X}}=7.6$; $\mathrm{SD}=0.8$; $\mathrm{N}=64$ ). A significant correlation between the SVL and mouth width was found (Pearson correlation: $r=0.86$; $\mathrm{p}<0.001 ; \mathrm{N}=64)$. The maximum volume of consumed prey per individual did not present a significant correlation with the snout-vent length (Pearson correlation: $\mathrm{r}=0.16, \mathrm{p}>0.05 \mathrm{~N}=64$ or with the mouth length (Pearson correlation: $\mathrm{r}=0.14, \mathrm{p}>0.05 ; \mathrm{N}=64$ ).

Besides the invertebrates, in four individuals of B. granulosus the remainders of vegetal material (leaves and seeds) were found. In a male, part of a spawn was found, apparently from Bufonidae. Sand grains were present in six of the analysed individuals $(9.2 \%)$. In 8 individuals of Bufo granulosus, 32 nematodes were found $(\bar{X}=4 ; \mathrm{SD}=4.4)$.

\section{Discussion}

The results of this study indicated seasonal differences in the diet of Physalaemus cf. cicada. These differences can be related not only to the prey availability, but 

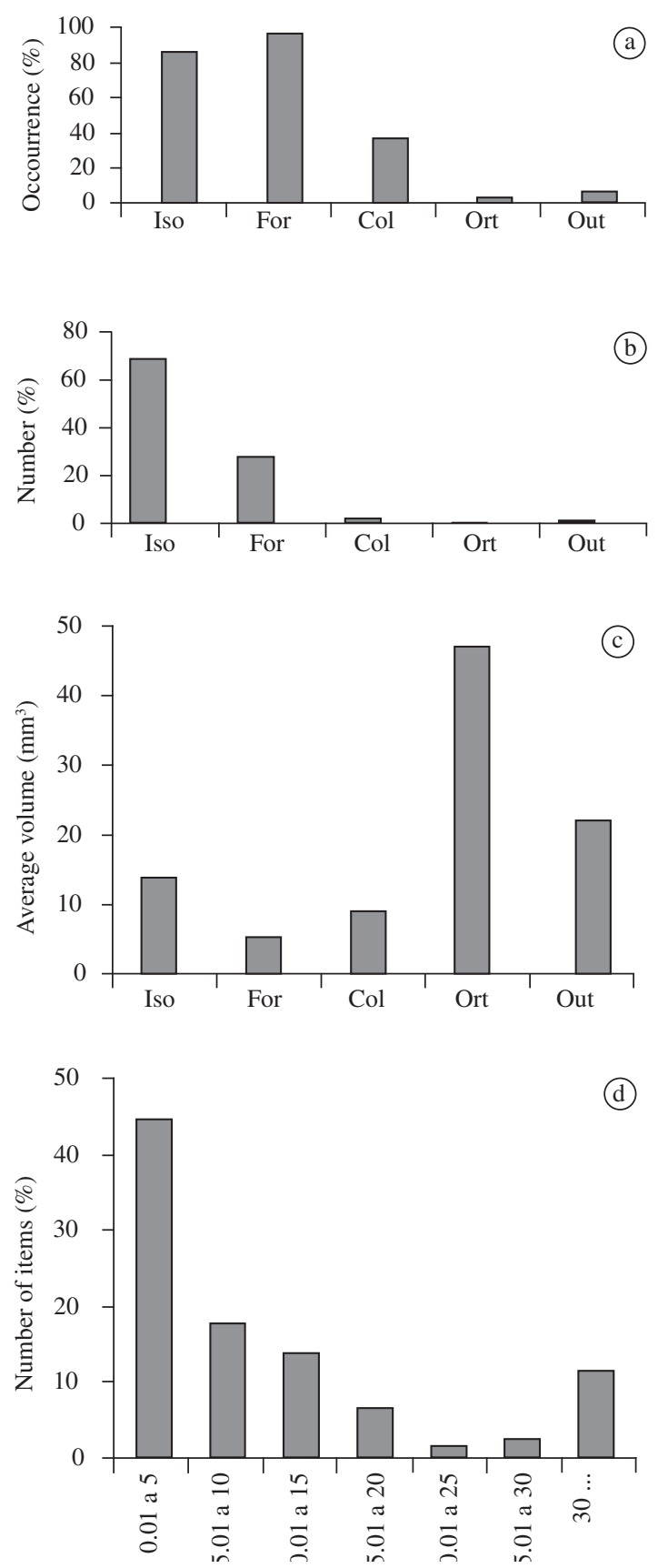

Figure 4. Frequency of occurrence a), numeric frequency b); average volume per category c); and number of items in different volumetric categories d) in Bufo granulosus in the rainy season. Iso = Isoptera; For = Formicidae; $\mathrm{Col}=$ Coleoptera Ort $=$ Orthoptera ; and Out $=$ Others .

also to the changes in the composition of the community of active anurans. In both seasons, $P$. cf. cicada presented a diet based mainly on Isoptera and Formicidae. In the rainy season, the number of termites found in gastrointestinal tracts was smaller than in the dry season, probably due to their lower availability in the environ- ment, and due to the presence of B. granulosus in the same season, since this species also consumed the same kind of food in large amounts. Furthermore, we found a significative positive correlation between the individual size of $P$. cf. cicada and maximum volume of consumed prey only in the rainy season.

Formicidae presented the largest abundance in the environment, but the frequency of occurrence and the numeric frequency were proportionally small when compared to their availability in the environment. This situation was reflected in the electivity index, which indicates the rejection of this food category. The increase in the consumption of the other categories during the rainy season also had an influence on the consumed prey size and maybe represents a compensation for the decrease in the consumption of the Isoptera, mentioned above.

A revision concerning the diet in anurans showed that the leptodactilids, in general, use a large diversity of prey in their diets (Parmelee, 1999). For example, Adenomera sp., consumed a large diversity of invertebrates (24 different categories) and presented on average, 6 prey per individual. Physalaemus cf. cicada also presented a similar number of prey per stomach. However, the number of food categories observed was a little smaller. Among the leptodactilids, Physalaemus petersi was the most distinct, because it presented a specialized diet in small prey and fed upon a large number of termites. Another leptodactilid, Eleutherodactylus peruvianus, which has a SVL similar to that found for $P$. cf. cicada, presented Orthoptera as the food category which was most important volumetrically (Parmelle 1999). Recent work regarding the diets of two leptodactilids, Physalaemus albifrons (Cruz, 2000) and Pleurodema diplolistris (Santos et al., 2003), in the dunes of the São Francisco river (Bahia, Brasil) showed similar results to ours. In both species, Isoptera had the largest numerical frequency and formicidae presented high occurrence frequency.

Toft (1981) and Strüssmann et al. (1984) consider that leptodactilids consume ants in a proportion much smaller than that found in the environment, insomuch as this family is generally named as non-ant specialists. Toft (1981) did not study the genus Physalaemus, but 7 of the 9 species of Eleutherodactylus (Leptodactylidae) observed were considered non-ant specialists and the two other species consumed ants in a proportion similar to that found in the environment. In another study, Leptodactylus ocellatus presented a large amount of ants in the stomach, followed by Hemiptera and Coleoptera (Strüssmann et al., 1984). The termites were not consumed much by the studied leptodactilids in both mentioned pieces of work.

Isoptera and Formicidae, whose numeric importance in the diet of P. cf. cicada was high in both seasons, were radically different concerning the availability in the environment. This result could be due to the methodology used to sample the preys. In this study we used pitfall traps, which present the disadvantage of only capturing animals that are moving on the soil. The termites are 
colonial animals and present a restricted area of activity on the soil (Barnes, 1984) and this would make their capture in this kind of trap difficult. However, at least in one study that did not use soil traps to evaluate the prey availability in the environment (Strüssmann et al., 1984), the result was similar.

Although there was a rejection of the category Formicidae in the dry season, which could be induced to a classification of $P$. cf. cicada as a non-ant specialist species, there was also a rejection of other categories, with the exception of Isoptera, whose electivity index indicated a remarkable food preference in both seasons. Moreover, the electivity index for the Formicidae category in the rainy season indicated that there was a consumption of this category in a proportion similar to that found in the environment.

As $P$. cf. cicada, B. granulosus presented Isoptera as the most important category numerically, followed by Formicidae. However, Coleoptera was the third most important category for Bufo granulosus. The size of the prey consumed by $B$. granulosus was very similar to those consumed by $P$. cf. cicada, but the average number of consumed items by the individuals of $B$. granulosus was much larger and this seems to be related to their larger size.

Some authors propose that species of Bufonidae presented similar diets, using specially ants, beetles, and other prey (Parmelee, 1999; Toft, 1981). For Bufo marinus, in some work done in Venezuela, Coleoptera and Formicidae were the most important food categories in terms of biomass, while Isoptera was insignificant (Evans and Lampo, 1996). On the other hand, Strussmann et al. (1984), in Manaus, Amazonas, Brazil found similar results for Bufo marinus and for B. granulosus, showing that the diet of the first species probably varies, depending on the prey availability and from the characteristics of the environment where the species occurs.

From the electivity index, Toft (1980 and 1981) observed that Bufo typhonius fed preferentially on ants in the dry and the rainy season and the Orthoptera category was rejected in the rainy season. Bufo granulosus, however, consumed ants in the same proportion to that found in the environment, while the termites were consumed in a much larger proportion. In relation to the other food categories, they were rejected by Bufo granulosus.

Different authors have registered the presence of parasites in the gastrointestinal tracts of anurans. Wheater (1986) demonstrated that the number of parasites is directly proportional to the size of the individual. Bufo granulosus presented an average in length larger than Physalaemus cf. cicada, and also more parasites. Nevertheless, the specific identification of the parasites was not performed. The sand grains found in the stomachs of the individuals of $B$. granulosus and $P$. cf. cicada, as mentioned by Evans and Lampo (1995), could help in the mechanical decomposition of items, such as the elytra of beetles. In relation to the vegetal material it might be ingested accidentally.
According to the methodology used in this study and from the electivity index, we can consider Bufo granulosus and Physalaemus cf. cicada as specialists in Isoptera. However, the third most consumed food category by $B$. granulosus was Coleoptera, while $P$. cf. $\mathrm{ci}$ cada in used Orthoptera the dry season, and in the rainy season Orthoptera and Coleoptera were approximately the same amount, as the third and fourth most consumed categories, respectively. Orthoptera was the category of most volumetric importance and presented a great availability in the environment when compared to Coleoptera. However, in the B. granulosus diet, Coleoptera presented low frequencies (numerical and of occurrence).

Acknowledgments - We are grateful to Prof. Dr. Freddy RB. Quijano and to the biologist Ivan Farias Castro for helping us identify the arthropods and to the biologists Carlos Liverton da S. Borges, Liliane A. dos Santos, and André Luis G. Matos for their aid in the field. Our special thanks go to the biologist Silvana Araújo da Silva for her dedication in the lab work and in the field and Roseane Sampaio Santiago for helping in the lab work. CNPq and UEFS supported this work.

\section{References}

ARZABE, C., 1999. Reproductive activity patterns of anurans in two different altitudinal sites within the Brazilian Caatinga. Revta. Bras. Zool., vol. 16, no. 3, p. 851-864.

BAHIA-SEPLANTEC., 1978. Informações básicas dos municípios baianos por microrregiões homogêneas. Salvador, CEPLAB.

BARNES, RD., 1984. Zoologia dos Invertebrados. Liv Roca Ltda, São Paulo, $4^{\text {th }}$ ed, 1179 p.

BOKERMANN, WCA., 1966. Notas sobre três espécies de Physalaemus de Maracás, Bahia (Amphibia, Leptodactylidae). Rev. Bras. Biol., vol. 26, no. 3, p. 253-259.

CALDWELL, JP. and VITT, LJ., 1999. Dietary asymmetry in leaf litter frogs and lizards in a transitional northern Amazonian rain forest. OIKOS, vol. 84, no. 3, p. 383-397.

CRUZ,LC., 2000.Utilização de RecursosEspaciaiseAlimentares por Physalaemus albifrons (Anura: Leptodactylidae) das Dunas do Rio São Francisco, Bahia, 2000 Salvador: Monografia de Bacharelado - Instituto de Ciências Biológicas da UFBA.

DUELLMAN, WE. and TRUEB L., 1994. Biology of Amphibians. Baltimore and London. The John Hopkins University Press, 670 p.

EVANS, M. and LAMPO, M., 1996. Diet of Bufo marinus in Venezuela. J.Herpetol., vol. 30, no. 1, p. 73-76.

FROST, DR., GRANT, T., FAIVOVICH, J., BAIN, RH., HAAS, A., HADDAD, CFB., DE SÁ, RO., CHANNING, A., WILKINSON, M., DONNELLAN, SC., RAXWORTHY, CJ., CAMPBELL, JA., BLOTTO, BL., MOLER, P., DREWES, RC., NUSSBAUM, RA., LYNCH, JD., GREEN, DM. and WHEELER, WC. 2006. The Amphibian Tree of Life. Bulletin of the American Museum of Natural History, no. 297, p. 1-370.

GRANT, T., FROST, DR., CALDWELL, JP., GAGLIARDO, R., HADDAD, CFB., KOK, PJR., MEANS, DB., NOONAN, BP., SCHARGEL, WE., WHEELER, W. 2006. Phylogenetic systematics of dart-poison frogs and their relatives (Amphibia, 
Athesphatanura, Dendrobatidae). Bulletin of the American Museum of Natural History, no. 299, p. 1-262.

JACOBS, J., 1974. Quantitative measurement of food seletion: A modification of the forage ratio and Ivlev's Electivity Index. Oecologia, vol. 14, no. 4, p. 413-417.

PARMELEE, JR., 1999. Trophic Ecology of a Tropical Anuran Assemblage. Scientific papers of Natural History Museum the University of Kansas, vol. 11, p. 1-59.

SANTOS, JWA., DAMASCENO, RP. and ROCHA, PLB., 2003. Feeding habits of the frog Pleurodema diplolistris (Anura, Leptodactylidae) in Quaternary sand dunes of the Middle Rio São Francisco, Bahia, Brazil. Phyllomedusa, vol. 2, no. 2, p. 83-92.
STRUSMANN, C., VALE, MBR., MENEGHINI, MN. and MAGNUSSON, NC., 1984. Diet and Foraging Mode of Bufo marinus e Leptodactylus ocellatus. J. Herpetology, vol. 18, no. 2, p. 138-146.

TOFT, CA., 1980. Feeding Ecology of Thirteen Syntopic Species of Anurans in a Seasonal Tropical Enviroment. Oecologia (Berl.), vol. 45, no. 1, p. 131-141.

-, 1981. Feeding Ecology of Panamanian Litter Anurans: Patterns in Diet and Foraging Mode. J.Herpetology, vol. 15 , no. 2, p. 139-144.

WHEATER, CP., 1986. Prey-size and parasite relationships in the common toad Bufo bufo. Herpetological Journal, vol. 1, no. 2, p. 62-66. 